\title{
Exogenous brand crises: brand infection and contamination
}

\author{
Kimberly A. Whitler ${ }^{1} \cdot$ Ali Besharat $^{2}$ (D) Saim Kashmiri ${ }^{3}$
}

Accepted: 21 December 2020 / Published online: 13 January 2021

(C) The Author(s), under exclusive licence to Springer Science+Business Media, LLC part of Springer Nature 2021

\begin{abstract}
Although there is an established literature regarding brand transgressions, Covid-19 has highlighted the need to better understand exogenously created brand crises. We introduce, define, and distinguish between two types of crises that emanate from exogenous, offending brands and the broader marketplace - brand infection and brand contamination. We further present future research ideas that can provide insights into the prevention, mitigation, and recovery strategies that firms can employ to address exogenously created brand crises.
\end{abstract}

Keywords Brand crisis · External crisis · Brand contamination · Brand transgression · Brand infection

\section{Distinguishing between different types of brand crises}

Whether it is the Samsung Note 7 batteries catching fire, the VW emissions scandal, the Target data breach that negatively affected the US retail industry, or the Covid-19 pandemic that damaged the health of many brands across the world, there is no shortage of events that can negatively impact brands (e.g., Kashmiri et al. 2017).

Kimberly A. Whitler, Ali Besharat and Saim Kashmiri contributed equally to this work.

Kimberly A. Whitler

WhitlerK@darden.virginia.edu

Ali Besharat

ali.besharat@du.edu

Saim Kashmiri

skashmir@olemiss.edu

1 Darden School of Business, University of Virginia, Charlottesville, VA, USA

2 Daniels College of Business, University of Denver, Denver, CO, USA

3 School of Business Administration, University of Mississippi, Oxford, MS, USA 
Referred to as brand crises, these unexpected incidents create significant challenges for businesses as they negatively impact the overall firm reputation (Dutta and Pullig 2011). Extant literature has focused primarily on self-inflicted wounds through the lens of brand transgressions, i.e., acts of omission or commission that negatively impact customer expectations, firm evaluation, and performance (Cleeren et al. 2008).

There are two primary types of brand transgressions - performance-based (a brand fails to deliver functional benefits) and value-based (a brand violates social or ethical norms). Examples of performance-based transgressions include product safety concerns such as Toyota's accelerator pedal recall and service failures such as TJX's inability to protect the private information of customers from hackers. Examples of value-based transgressions include ethical concerns such as CrossFit CEO's inflammatory tweets comparing the death of George Floyd to Covid-19.

While brand transgressions are a type of brand crisis, the Covid-19 pandemic has highlighted the need to consider those that are not self-inflicted, as much of the extant literature stops short of identifying or investigating crises that are exogenously created (see Grewal et al. 2007 for an exception). Consequently, it is unclear how exogenously created brand crises manifest differently from brand transgressions.

We extend current literature and introduce two types of externally created brand crises, which we refer to as brand infection and brand contamination (see Table 1). The three key criteria which help differentiate between brand infection and contamination are the level of impact, the route to brand injury, and the process of brand damage. We define "brand infection" as an unexpected event that causes damage to a brand through no fault of the focal brand other than its shared associations with and/or proximity to a transgressing brand. In other words, brand infection is an outcome wherein the focal brand suffers following another brand's transgression. The transgressing action that leads to brand infection happens from another brand, often from within the infected brand's industry. The route to injury in this case is the transfer of negative impact from the transgressing brand to other proximal and/or associated brands (i.e., brand-to-brand damage transfer), which could ultimately hurt business outcomes. For example, when the TransAsia Airways GE222 accident happened in Taiwan on July 23, 2014, the image, safety perception, and trust of other airlines among Taiwanese people were negatively affected ( $\mathrm{Li}$ et al. 2015). Reports of Tylenol poisonings led to an increased suspicion toward pain relief pills (Dahlen and Lange 2006). Recent research showed that when Wells Fargo employees opened more than 2 million banking and credit card accounts without customers' approval over a period of four years, public distrust of big banks grew significantly (Galella 2017).

In contrast, we define "brand contamination" as an injury that impacts a brand through an exogenous, unrelated event. In this case, an environmental event (e.g., economic, technological, health crises) often impacts a number of brands - none of which may share any association or similarity to the offending event. The route to injury for brand contamination is through environmental event-to-brand damage transfer. In addition, the process of brand damage for brand contamination is different as it often affects business results first which may then weaken the brand image later in the form of distrust, and/or concerns about the brand's financial sustainability. For instance, several firms such as Gold's Gym, Hertz, and Neiman Marcus filed for bankruptcy due to the Covid-19 pandemic. In this case, these firms had not committed a brand transgression, nor were they experiencing spillover from a similar firm's transgression. 
Table 1 Descriptions and attributes of brand transgression, brand infection, and brand contamination

\begin{tabular}{|c|c|c|c|}
\hline & Brand transgression & Brand infection & Brand contamination \\
\hline Definition & $\begin{array}{l}\text { Self-inflicted injury that } \\
\text { violates customer } \\
\text { expectations through acts } \\
\text { of omission or commission }\end{array}$ & $\begin{array}{l}\text { An Injury that occurs through } \\
\text { no fault of the focal brand } \\
\text { other than shared } \\
\text { associations and/or proximi- } \\
\text { ty to a brand that has } \\
\text { transgressed }\end{array}$ & $\begin{array}{l}\text { An Injury that occurs through } \\
\text { no fault of the focal brand } \\
\text { and no shared } \\
\text { associations/similarities with } \\
\text { another brand that results } \\
\text { from an unexpected, unre- } \\
\text { lated event }\end{array}$ \\
\hline Source & Endogenous & Exogenous & Exogenous \\
\hline $\begin{array}{l}\text { Level of } \\
\text { impact }\end{array}$ & Focal firm & $\begin{array}{l}\text { Another firm, typically in the } \\
\text { focal firm's industry }\end{array}$ & Environmental \\
\hline $\begin{array}{l}\text { Route of } \\
\text { injury }\end{array}$ & Self-inflicted & $\begin{array}{l}\text { Guilty by association, proximal } \\
\text { spillover (brand-to-brand } \\
\text { damage transfer) }\end{array}$ & $\begin{array}{l}\text { Non-proximal spillover } \\
\text { (environmental } \\
\text { event-to-brand damage } \\
\text { transfer) }\end{array}$ \\
\hline $\begin{array}{l}\text { Process of } \\
\text { brand } \\
\text { damage }\end{array}$ & Brand image distortion & $\begin{array}{l}\text { Brand-to-brand image } \\
\text { distortion }\end{array}$ & $\begin{array}{l}\text { Environmental event-to -Brand } \\
\text { image distortion }\end{array}$ \\
\hline $\begin{array}{l}\text { Examples } \\
\text { of } \\
\text { types }\end{array}$ & Performance and value & Performance and value & $\begin{array}{l}\text { Natural, social, technological, } \\
\text { financial, or political }\end{array}$ \\
\hline Examples & $\begin{array}{l}\text { Samsung Note } 7 \\
\text { (performance), Toyota } \\
\text { accelerator (performance), } \\
\text { VW emissions fabrication } \\
\text { (values) }\end{array}$ & $\begin{array}{l}\text { ValuJet's flight } 592 \text { crash that } \\
\text { negatively impacted other } \\
\text { low-cost airlines, Wells Far- } \\
\text { go scandal negatively affect- } \\
\text { ed other big banks, } \\
\text { British petroleum's Oil spill } \\
\text { adversely affected a number } \\
\text { of brands in the oil and gas } \\
\text { industry }\end{array}$ & $\begin{array}{l}\text { Covid-19 (natural), Recession } \\
\quad \text { (financial), Y2K } \\
\quad \text { (technological), } 9 / 11 \\
\quad \text { (terrorism), Brexit (political) }\end{array}$ \\
\hline
\end{tabular}

However, Covid-19 led to a decline in consumers' demand and this decline in turn led to consumer concerns regarding some brands' financial sustainability. Similarly, on November 26, 2008, the commercial hub of India suffered a terrorist track with terrorists carrying out 12 synchronized attacks lasting four days across Mumbai. According to some estimates, hotels in India faced a $60 \%$ cancelation in bookings and the Indian economy lost US $\$ 100$ billion in the immediate aftermath of the attack (Knowledgeindia@wharton.com 2008). According to researchers, the immediate economic loss was also followed by a damage to "Brand India" as the terrorist attack negatively affected brand India's image from an image of safety and travel-friendliness to an image of increased risk, danger, and vulnerability (Balakrishnan 2011).

\section{Future research agenda for exogenously created brand crises}

Below, we identify three areas of research that address factors that provide insight on how firms can handle brand crises. 


\subsection{Brand crisis prevention}

Future research should explore certain structural factors which can help protect brands from exogenous events. Does the presence of specific leadership positions (e.g., Chief Risk Officer) help?

Do certain marketing-related strategies help insulate and prevent an exogenous brand crisis event? Are these strategies unique to the type of exogenous brand crisis? Does effective customer relationship management improve firms' chances of minimizing brand contamination? Are brands that have brand image leadership on functional equities able to better insulate themselves from an exogenous event? To what degree does a favorable precrisis reputation serve as a buffer to mitigate the negative impact of an exogenous crisis? Finally, how might a brand strategy (e.g., a house-of-brands strategy) increase a firm's ability to prevent an exogenous event from impacting the firm?

\subsection{Brand crisis mitigation}

There is little insight into the role that firms' upper echelons play in influencing the corporate brand (Whitler et al. 2020), particularly during an exogenously created crisis. Does or should the level of the upper echelons' engagement vary across types of brand crises? How do the roles change when each upper-echelons level has customercentered, output-oriented (e.g., marketing and sales) inclusion? How do the characteristics of the CEO (e.g., CEO narcissism and CEO regulatory focus) influence reaction to and management of brand crises (Kashmiri et al. 2019)? Do specific characteristics of business executives (e.g., functional background) impact the management of brand crises? Are these characteristics vary across different brand crises?

What are the types of marketing strategies firms employ to mitigate brand crises? What is the role of speed of response to crises? How do firms use different communication channels during a crisis and with what effect? What is the variance in the communication message strategies (e.g., nothing, excuse, justification, apology, and denial) and with what consequence?

\subsection{Brand crisis recovery}

What are the firm attributes that can influence the length and severity of brand damage? What external attributes might dampen brand recovery, such as whether the transgressing brand is from the same country? How might factors related to upper echelons, such as tenure or heterogeneity, help or hurt recovery? How might upper echelons' heterogeneity help or hurt decision-making during a crisis recovery? Under what conditions do executives engage with consumers to help facilitate recovery, with what types of messages, and with what consequences? For example, after the Covid-19 pandemic hit, American Airlines sent videos of their CEO embedded in emails to consumers. In contrast, Southwest Airlines sent emails from their SVP and CMO.

\subsection{Across the prevention, mitigation, and recovery process}

How do firm communication strategies evolve during the different stages of a crisis and with what effect? At the beginning of the Covid-19 pandemic, the tone of a number of 
US companies seemed to communicate a degree of uncertainty. Over time, the tone of these companies shifted to warmth and hope (e.g., Amazon). Later, some brands employed humor, such as Jeep's update to their successful Super Bowl Groundhog Day ad. How do changes in the tone influence consumer perceptions during crises?

Who should be the target of crisis-stricken brands' public messages? Covid-19 suggested that that various stakeholders might be involved, such as consumers, employees, and shareholders. Under what conditions is it effective for brands to target different stakeholders and at what stage of crisis? Finally, what types of organizations are more receptive to learning from a crisis and open to structural changes?

\section{References}

Balakrishnan, M. S. (2011). Protecting from brand burn during times of crisis: Mumbai 26/11: A case of the Taj Mahal Palace and Tower Hotel. Management Research Review, 34(12), 1309-1334.

Cleeren, K., Dekimpe, M. G., \& Helsen, K. (2008). Weathering product-harm crises. Journal of the Academy of Marketing Science, 36(2), 262-270.

Dahlen, M., \& Lange, F. (2006). A disaster is contagious: How a brand in crisis affects other brands. Journal of Advertising Research, 46(4), 388-397.

Dutta, S., \& Pullig, C. (2011). Effectiveness of corporate responses to brand crises: The role of crisis type and response strategies. Journal of Business Research, 64(12), 1281-1287.

Galella, A. (2017). Post-Wells Fargo scandals, Consumers trust big banks less than they trust Charlie Sheen and Tiger Woods. Retrieved from https://www.businesswire.com/news/home/20170921005361/en/NewSurvey-Post-Wells-Fargo-Scandals-Consumers-Trust

Grewal, R., Johnson, J. L., \& Sarker, S. (2007). Crises in business markets: Implications for interfirm linkages. Journal of the Academy of Marketing Science, 35(3), 398-416.

Kashmiri, S., Nicol, C. D., \& Hsu, L. (2017). Birds of a feather: Intra-industry spillover of the Target customer data breach and the shielding role of IT, marketing, and CSR. Journal of Academy of Marketing Science, 45(2), 208-228.

Kashmiri, S., Gala, P., \& Nicol, C. D. (2019). Seeking pleasure or avoiding pain: Influence of CEO regulatory focus on firms' advertising, R\&D, and marketing controversies. Journal of Business Research, 105, 227242.

Knowledgeindia@wharton.com (2008), “Terrorist attacks will further weaken a slowing Indian economy”, December 11, available at: https://knowledge.wharton.upenn.edu/article/terrorist-attacks-will-furtherweaken-a-slowing-indian-economy/ (Accessed 21 Nov 2020).

Li, C. W., Phun, V. K., Suzuki, M., \& Yai, T. (2015). The effects of aviation accidents on public perception toward an airline. Journal of the Eastern Asia Society for Transportation Studies, 11, 2347-2362.

Whitler, K. A., Morgan, N. A., \& Rego, L. (2020). The impact of chief marketing officer role variance on marketing capability. Marketing Science Institute, 20-112.

Publisher's note Springer Nature remains neutral with regard to jurisdictional claims in published maps and institutional affiliations. 